\title{
Copepod egg production rates in the Pomeranian Bay (Southern Baltic Sea) as a function of phytoplankton abundance and taxonomic composition
}

\author{
Katrin Schmidt*, Paul Kähler, Bodo von Bodungen \\ Institut für Ostseeforschung an der Universität Rostock, Seestraße 15, D-18119 Rostock, Germany
}

\begin{abstract}
The copepod community of the Pomeranian Bay, in the outer part of the Oder Estuary (Southern Baltic Sea), is dominated by Acartia bifilosa Giesbrecht in winter and spring and by $A$. tonsa Dana in autumn. During summer both species co-occur. The egg production of these species was studied in 1994/1995. Rates (eggs female ${ }^{-1} \mathrm{~d}^{-1}$ ) were found to vary both seasonally and spatially. In winter, egg production rates of $A$. bifilosa were low, but showed a positive response to increasing chlorophyll a concentrations. During the late phase of the spring bloom (dominated by the diatom Skeletonema costatum), egg production of A. bifilosa was clearly higher than in winter, while water temperature remained at a low level. Phytoplankton concentrations during the spring bloom varied, but egg production rates were uniform all over the bay, suggesting production was not food limited Length-specific weight and lipid content indicate that females were in good physiological condition. During summer and autumn, both high and very low egg production rates were observed for both species. The relation between egg production rate and chlorophyll a concentration was negative. The analysis of the phytoplankton composition in summer suggested that a high proportion of dinoflagellates was beneficial for egg production whereas high proportions of cyanobacterial colonies and filaments had negative effects. Except during the spring bloom period, the egg production of Acartia spp. in the Pomeranian Bay was limited by the amount and quality of phytoplankton.
\end{abstract}

KEY WORDS: Acartia spp. Egg production - Phytoplankton - Food quality Pomeranian Bay

\section{INTRODUCTION}

In the pelagic food chain, copepods are a principal link between microplankton and larger predators. The egg production rate (eggs females ${ }^{-1} \mathrm{~d}^{-1}$ ) represents the potential recruitment of a copepod stock, although the actual offspring are formed by viable nauplii. Species which do not rely on stored food reserves show a fast response in egg production to variations in food availability. The egg production rate of Acartia tonsa increases sigmoidally with food concentration when a valuable diet is offered in the laboratory (Kiørboe et al. 1985). Since phytoplankton is an important food source

\footnotetext{
•E-mail: katrin.schmidt@io-warnemuende.de
}

for calanoid copepods, chlorophyll a (chl a) concentration has often been used as a measure of food supply in field studies. Some authors found fair correlations between copepod egg production and phytoplankton standing stock (e.g. Landry 1978, Checkley 1980, Durbin et al. 1983, Beckman \& Petersen 1986, Kiørboe \& Johanson 1986), while others did not (e g. Dagg 1978, Ambler 1986, Kimmerer \& McKinnon 1987, Bautista et al. 1994, Hay 1995). Mostly, 2 factors kave been discussed as being responsible for poor correlations between egg production and chl a concentration: the alternative ingestion of microzooplankton (Gifford \& Dagg 1991, White \& Roman 1992, Dam et al. 1994) and variations in the quality of phytoplankton (e.g. Bellantoni \& Petersen 1987, Kimmerer \& McKinnon 1987, Ianora \& Scotto di Carlo 1988, Kiørboe et al. 1988). 
The importance of food quality for egg production is obvious since, firstly, the rate at which particles are captured and ingested by copepods depends on their size and shape (Frost 1972, Cowles 1979, Vanderploeg et al. 1988) and, secondly, the composition of crustacean eggs includes a number of essential components (e.g. Sargent \& Falk-Petersen 1988, Harrison 1990, Pond et al. 1996) which different food sources may or may not supply. Laboratory studies on the effect of food quality on copepod egg production have a long tradition (e.g. Marshall \& Orr 1952, Checkley 1980, Cahoon 1981, Donaghay 1985, Støttrup \& Jensen 1990, Jónasdóttir 1994), but there have been only a few field studies (Kleppel 1992, Jónasdóttir et al. 1995, Pond et al. 1996).

Even though food assimilation is the basis of any production, physiological rates are influenced by a number of additional factors, among which temperature has been recognized as especially important. Hence, egg production is also a function of temperature and, indeed, several authors have considered temperature as the principal parameter affecting egg production in the field (Castel \& Feurtet 1989, Uye \& Shibuno 1992, White \& Roman 1992). Other investigators have demonstrated food limitation of zooplankton in the field by comparing egg production or somatic growth of animals incubated in ambient water with egg production of animals from the same environment fed on cultured algae of high nutritional quality (Durbin et al. 1983, 1992, Ambler 1985, Donaghay 1985, Mueller-Navarra \& Lampert 1996).

The purpose of the present study was to examine the effect of differently composed phytoplankton communities on copepod egg production in the field. A simple approach was used to separate the effect of phytoplankton food from that of temperature: several stations of a heterogeneous environment, where phytoplankton abundance and composition varied while temperature was uniform, were sampled within a short period. Such conditions prevailed in the outer part of the Oder Estuary (Pomeranian Bay, Southern Baltic Sea) during cruises in June and September 1994 and January, April and June 1995. Copepods of the genus Acartia were used in the experiments as they account for at least $70 \%$ of the calanoid copepods, which are the most important component of the zooplankton in the Pomeranian Bay on an annual basis (authors unpubl. data).

\section{MATERIALS AND METHODS}

The Pomeranian Bay. Three main characteristics of the Pomeranian Bay are: (1) heterogeneous mixing of the nutrient-rich river water with water of the open Baltic Sea causes strong temporal and spatial variations in phytoplankton abundance and species composition, (2) the salinity gradient from the river mouths to the outer parts of the bay is weak, the open Baltic Sea itself being mesohaline and (3) the water is shallow (maximum depth $20 \mathrm{~m}$ ) and forcing winds keep the water column almost permanently mixed. These conditions enabled us to encounter different phytoplankton communities with a relatively uniform background of temperature and salinity.

The cruises. Dates of cruises, number of sampled stations, average temperature and ranges of salinity are given in Table 1. In June/July 1994 the ship followed the trajectory of a drifter deployed into the river plume close to the mouth of the Swina (the largest of the 3 outlets of the Odra Lagoon), and moved into the open bay. During the other cruises, except for August 1995, the ship sampled a grid of stations covering the Pomeranian Bay (Fig. 1). The cruise in August 1995 was a grid survey from the outermost southwest of the Baltic to the Bornholms Gatt (Fig. 1) which included the Pomeranian Bay. Temperature and salinity data were measured by CTD (OMCTD, Institut für Ostseeforschung, Warnemünde).

Phytoplankton analyses. Ambient chl a concentrations were determined at each station. Water from 3 depths was filtered onto GF/F filters, which were stored at $-18^{\circ} \mathrm{C}$ until samples could be processed and measured fluorometrically (Turner Designs fluorometer). In addition to total chl a concentration, the chl a concentration of the $>8 \mu \mathrm{m}$ fraction was measured in April 1995 and June/July 1995. For fractionation, cellulose nitrate filters (pore size: $8 \mu \mathrm{m}$ ) were used. Analyses of the taxonomic composition were carried out only at selected stations. Cells were counted and measured using an inverted microscope following the recommendations of Edler (1979). Single algae smaller than $5 \mu \mathrm{m}$ were not included in the counts.

Egg production experiments. Egg production experiments were generally started in the morning. Copepods were collected in several vertical tows using a WP-2 net (200 $\mathrm{\mu m}$ mesh size). Copepods were immediately transferred to the dark box of a light trap con-

Table 1 Data from cruises in the Pomeranian Bay: date, number of stations sampled, average temperature $( \pm \mathrm{SD})$, range of salinities and average $\mathrm{ch}$ a concentration $( \pm \mathrm{SD})$

\begin{tabular}{|lrccc|}
\hline Date & Stn & \multicolumn{1}{c}{$\begin{array}{c}\text { Temp } \\
\left({ }^{\circ} \mathrm{C}\right)\end{array}$} & $\begin{array}{c}\text { Salinity } \\
(\%)\end{array}$ & $\begin{array}{c}\text { Chl a } \\
\left(\mathrm{\mu g} \mathrm{l}^{-1}\right)\end{array}$ \\
\hline 26 Jun-6 Jul 1994 & 11 & $16.5 \pm 1.5$ & $4-8$ & $11.6 \pm 5$ \\
21 Sep-27 Sep 1994 & 9 & $14.5 \pm 0.5$ & $4-8$ & $4.8 \pm 2.1$ \\
17 Jan-29 Jan 1995 & 14 & $1.3 \pm 0.8$ & $7-9$ & $1.5 \pm 0.8$ \\
5 Apr-20 Apr 1995 & 18 & $4.8 \pm 0.4$ & $7-9$ & $5.1 \pm 3.1$ \\
28 Jun-9 Jul 1995 & 17 & $16.4 \pm 1.5$ & $7-9$ & $5.3 \pm 5.5$ \\
\hline
\end{tabular}




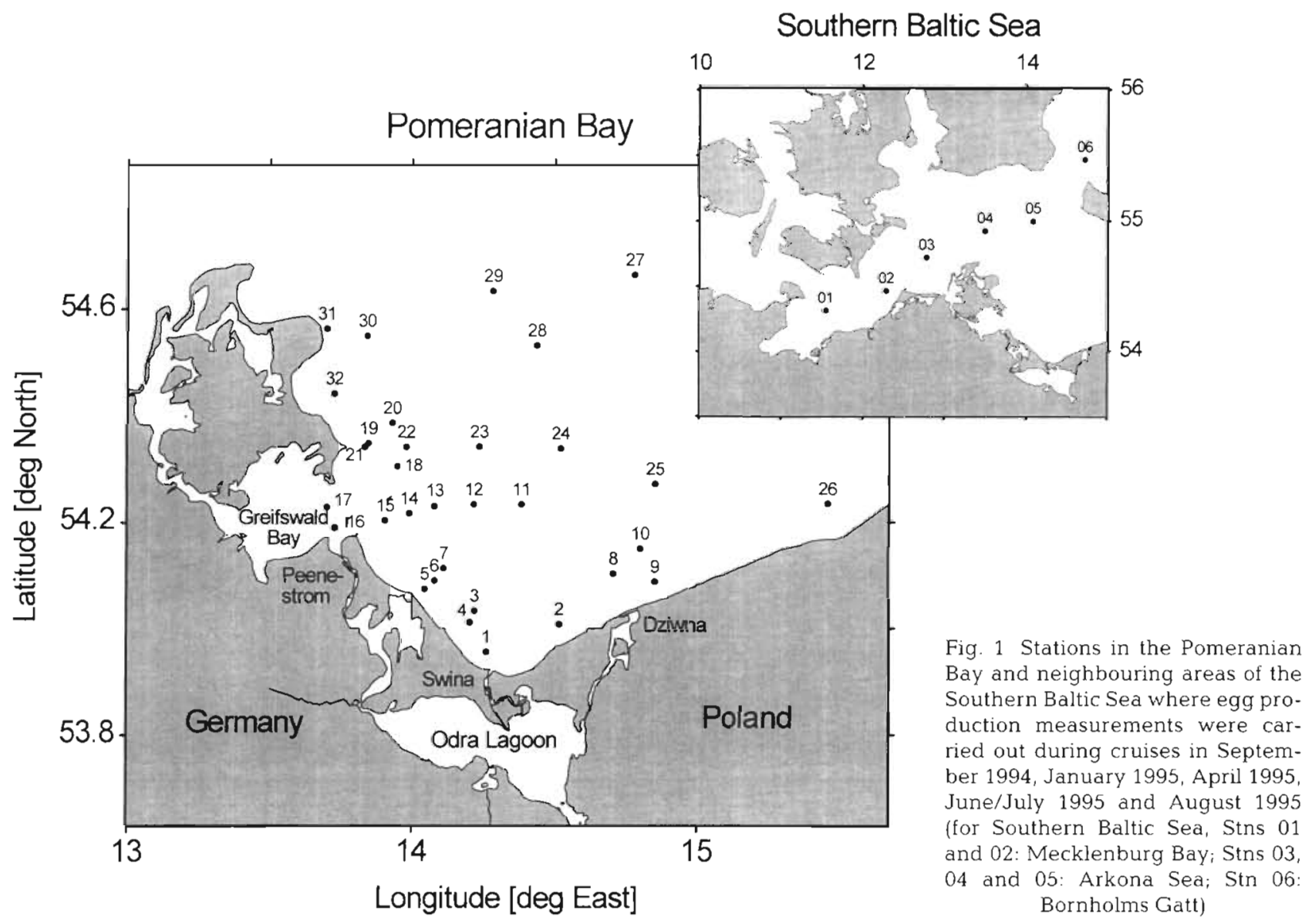

taining ambient water as described by Behrendt \& Krocker (1990). The light box of the trap was filled with GF/F-filtered ambient water. Using the light trap, active individuals could be isolated from damaged ones as well as from phytoplankton within a few minutes in summer and within about $45 \mathrm{~min}$ in winter. Females of the dominant species of Acartia (A. bifilosa in June/July 1994, January 1995, April 1995; A. tonsa in September 1994; and both species in June/July 1995) were selected under a binocular microscope and individually placed into $350 \mu \mathrm{l}$ wells of a Micro Plate (Linbro). Generally, 96, but at least 35, copepods were incubated. Wells were filled with freshly filtered ambient water, and the plates were stored at in situ water temperature and dim light. After $24 \mathrm{~h}$, the eggs of surviving females were counted directly in the flat-bottom wells using a binocular microscope. Empty egg shells and crumpled membranes were included to account for hatched eggs and eggs having been eaten (cf. Kiørboe et al. 1985, Tiselius et al. 1991, Dam et al. 1994, Ianora et al. 1994).

In situ egg production rates of individual females often vary considerably due to different specific fecundity, age, feeding history and behaviour (Båmstedt 1988, Laabir et al. 1995). Hence, for precise mea- surements a high number of replicates is necessary. Laabir et al. (1995) suggest incubating at least 30 females individually or in small batches. To be able to process a high number of individuals within a short period, we reduced the incubation volume drastically and counted the eggs directly in the micro wells in which the females had been incubated. The use of filtered water followed the assumption that egg production within $24 \mathrm{~h}$ largely relates to food intake prior to capture (e.g. Ianora \& Buttino 1990, Bautista et al. 1994). Egg production rates measured during the incubation in micro wells were similar to those obtained in larger containers ( $600 \mathrm{ml}$ bottles) if both were filled with filtered ambient water (Table 2). It seems that, even if the confinement induced stress for Acartia spp., their egg production, using the energy of previously ingested food, was negligibly affected. On the other hand, our test confirmed that the egg production rate of a small copepod species can be influenced by the food conditions during $24 \mathrm{~h}$ of incubation. In filtered water, egg production rates were 50 to $70 \%$ lower in autumn and about $30 \%$ lower in spring than in pre-screened ambient water $(<55 \mu \mathrm{m})$. Obviously, the degree of underestimation in filtered water varied with season. Additional parameters (length-specific 
Table 2. Acartia spp. Comparison of egg production rates (eggs female ${ }^{-1} \mathrm{~d}^{-1}, \pm \mathrm{SD}$ ) using 2 different incubation methods. Females were either incubated in batches of 3 in $600 \mathrm{ml}$ bottles filled with $<55 \mu \mathrm{m}$ ambient water or GF/F-filtered ambient water, or they were incubated individually in wells of a micro plate filled with GF/F-filtered ambient water. This test was carried out in September 1995 and March 1997, in addition to the other egg production experiments described in this study

\begin{tabular}{|c|c|c|c|}
\hline \multirow[t]{2}{*}{ Species } & \multicolumn{2}{|c|}{$\begin{array}{l}\text { Bottle incubation } \\
\qquad(\mathrm{n}=5)\end{array}$} & \multirow{2}{*}{$\begin{array}{c}\text { Micro plate incubatior } \\
(\mathrm{n}=96) \\
\text { Filtered } \\
\text { seawater }\end{array}$} \\
\hline & $\begin{array}{l}<55 \mu \mathrm{m} \\
\text { seawater }\end{array}$ & $\begin{array}{l}\text { Filtered } \\
\text { seawater }\end{array}$ & \\
\hline \multicolumn{4}{|c|}{ September $1995\left(11^{\circ} \mathrm{C}\right)$} \\
\hline \multirow[t]{6}{*}{ A. tonsa } & $2.2 \pm 0.6$ & $1.6 \pm 0.9$ & $1.2 \pm 1.3$ \\
\hline & $2.1 \pm 0.7$ & $1.0 \pm 0.2$ & $0.6 \pm 0.9$ \\
\hline & $4.2 \pm 1.3$ & $0.6 \pm 0.3$ & $1.1 \pm 1.2$ \\
\hline & $2.0 \pm 1.1$ & $1.4 \pm 0.6$ & $1.2 \pm 1.2$ \\
\hline & $3.3 \pm 1.1$ & $0.6 \pm 0.4$ & $1.2 \pm 1.2$ \\
\hline & $3.9 \pm 0.6$ & $1.3 \pm 0.3$ & $1.6 \pm 1.4$ \\
\hline \multicolumn{4}{|c|}{ March $1997\left(3^{\circ} \mathrm{C}\right)$} \\
\hline \multirow[t]{3}{*}{ A. bifilosa } & $16.5 \pm 7.0$ & $9.6 \pm 5.3$ & $10.2 \pm 6.2$ \\
\hline & $10.7 \pm 2.9$ & $7.3 \pm 4.5$ & $7.65 \pm 5.2$ \\
\hline & $9.2 \pm 4.7$ & $5.8 \pm 1.5$ & $6.7 \pm 4.6$ \\
\hline
\end{tabular}

weight and lipid content) were used to discuss seasonal differences in the condition of females. The effect of starvation during egg production experiments has been studied in more detail for Acartia grani by Saiz et al. (1997). Their data show that differences in egg production rates due to different food availability prior to the experiment will be reduced if copepods are incubated without food. Consequently, the differences obtained using the present method can be discussed without reservations as they are very likely even higher in the field.

Length-specific weight and lipid content. At each station a bulk of copepods was filtered on $100 \mu \mathrm{m}$ gauze after passing the light trap. The samples were stored in liquid nitrogen for later analyses. In the laboratory, specimens were washed from the gauze. The cephalothorax lengths of 50 Acartia spp. females were measured. About 300 individuals were placed onto a $\mathrm{GF} / \mathrm{F}$ filter, dried at $60^{\circ} \mathrm{C}$ and weighed on a microbalance. The length-specific weight (LSW), which is useful for comparing weight in animals of different lengths (Durbin et al. 1983), was computed as LSW = $W / L^{3}$, where $W$ is weight $(\mu g)$, and $L$ is cephalothorax length $(\mathrm{mm})$. Total lipid content was determined by the sulfophosphovanillin method of Zöllner \& Kirsch (1962). Absorbance was read at $530 \mathrm{~nm}$ and compared with a cholesterol standard.

Statistics. The Mann-Whitney $U$-test was used to determine whether the variance in medians of egg production rates, length-specific weights and lipid con- tents was significant. For correlation analysis between egg production rates and (1) concentration of chl $a_{1}$ (2) taxonomic composition of phytoplankton and (3) length-specific weight of females, pairwise Spearman rank correlation coefficients $\left(r_{S}\right)$ were calculated.

\section{RESULTS}

\section{Hydrography}

Water temperature in the Pomeranian Bay ranged from $1^{\circ} \mathrm{C}$ in winter to about $17^{\circ} \mathrm{C}$ in summer. Except for the cruise in August 1995, no stratification of the water column was observed. Even the lowest measured salinity of $4 \%$ was within the range to which Acartia bifilosa and $A$, tonsa are adapted in the Baltic Sea (Arndt 1985, Viitasalo et al. 1994 and references therein). During each cruise, maximal differences in temperature and salinity were low between the stations sampled $\left(3^{\circ} \mathrm{C}\right.$ and $4 \%$, respectively) and were not considered to influence the egg production rates significantly.

\section{Phytoplankton}

In general, the bay was characterized by relatively high standing stocks of phytoplankton (Table 1). The lowest chl a concentrations, measured in the outer parts of the bay, were $0.5 \mu \mathrm{g} \mathrm{I}^{-1}$ in January 1995 and $>1 \mathrm{ug} \mathrm{l}^{-1}$ during the cruises in September 1994, April 1995 and June/July 1995. Highest concentrations were observed near the outlets of the lagoon: $4 \mu \mathrm{g}$ chl a $\mathrm{l}^{-1}$ in January 1995, more than $20 \mu \mathrm{g} \mathrm{I}^{-1}$ during the drift-experiments in June/July 1994 and about $10 \mu \mathrm{g}$ $1^{-1}$ during the other cruises. Phytoplankton biomass was dominated by large cells, colonies and filaments. The $>8 \mu \mathrm{m}$ fraction of phytoplankton contributed $91 \pm 8 \%$ of the total chl a concentration in April 1995 and $79 \pm 6 \%$ in June/July 1995 .

The composition of phytoplankton differed between seasons as well as between stations. In April 1995, all stations were dominated by the diatom Skeletonema costatum, while, in September 1994, the dinoflagellate Prorocentrum micans was most abundant at the outer stations of the bay. In September 1994 at stations close to the coastline, as well as in June/July 1994, January 1995. June/July 1995 and August 1995 at all sampled stations, phytoplankton was a mixture of cyanobacteria, chlorophytes, diatoms, cryptophytes and dinoflagellates. For the cruises carried out in summer, a detailed presentation of the phytoplankton composition based on groups is given in Fig. 2 and the dominant species are named in Table 3. 
a) June/ July 1994

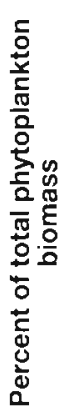

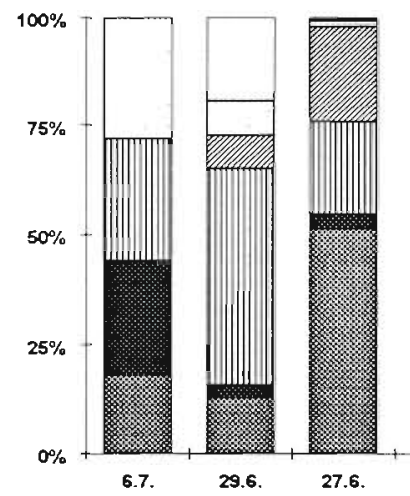

b) June/ July 1995

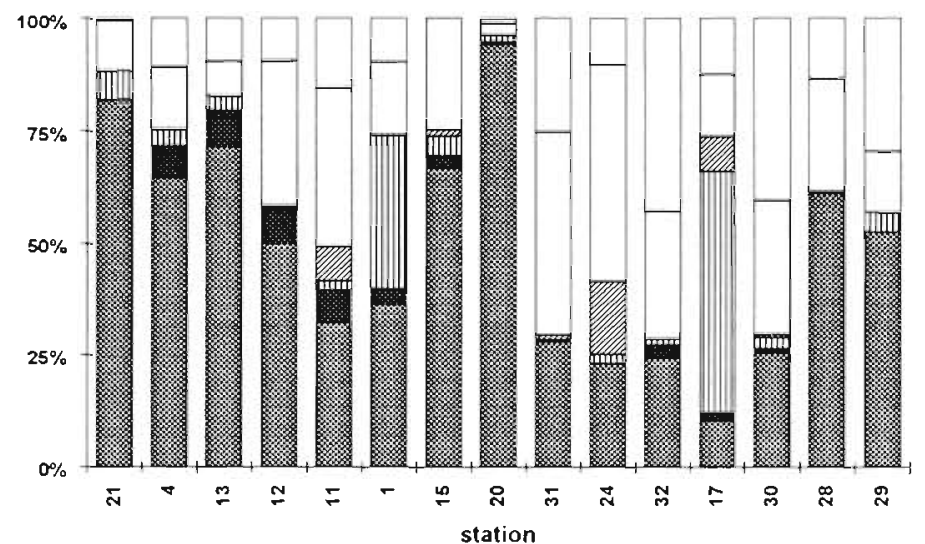

c) August 1995

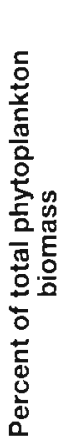$$
700 \%
$$<smiles>[Te]C1CCC1</smiles>

\section{每}
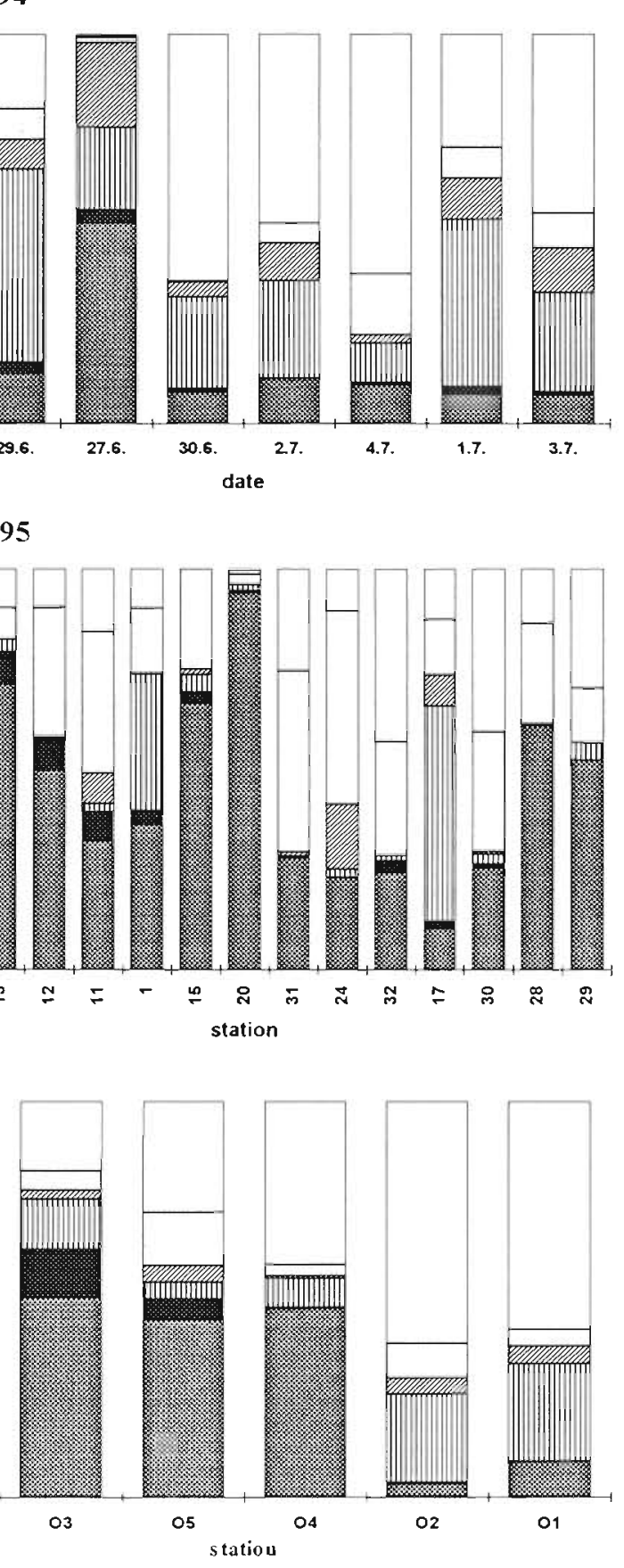

\section{-}




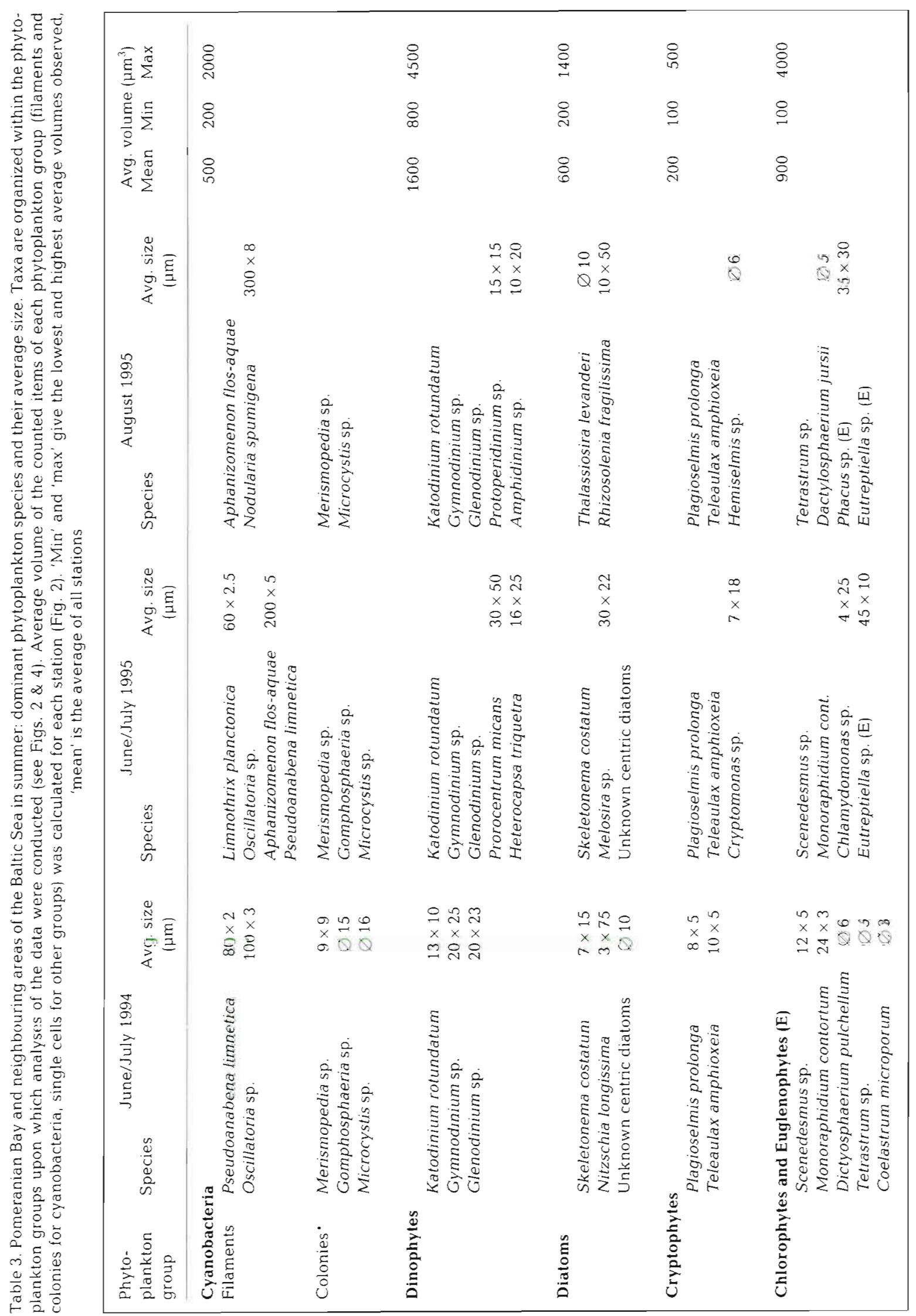


Table 4. Acartia bifilosa and A. tonsa. Egg production rates (eggs female ${ }^{-1} \mathrm{~d}^{-1}, \pm \mathrm{SD}$ ) in the Pomeranian Bay. June/July 1994: drift experiments near the mouth of the Swina (except for the mouth of the Peene storm on 27 June and central Greifswald Bay on 6 July). September 1994, and January, April and June/July 1995: stations covering the bay (see Fig. 1). Additional parameters measured were chl a concentration, phytoplankton composition, lipid content, and length-specific weight of females

\begin{tabular}{|c|c|c|c|c|c|c|c|}
\hline June/July & 1994 & Stn & September 1994 & January 1995 & April 1995 & June/Ju & 1995 \\
\hline A. bifilosa & (date) & & A. tonsa & A. bifilosa & A. bifilosa & A. bifilosa & A. tonsa \\
\hline $10.1 \pm 2.9^{\mathrm{abb}}$ & (25 Jun) & 1 & & & & $6.6 \pm 2.5^{\mathrm{cd}}$ & $5.5 \pm 3.1$ \\
\hline $7.6 \pm 6.2^{b}$ & (26 Jun) & 2 & & $0.6 \pm 0.8^{\mathrm{bd}}$ & $12.0 \pm 5.7$ & & \\
\hline $7.8 \pm 3.9$ & (26 Jun) & 3 & & $1.3 \pm 1.3^{d}$ & & & \\
\hline $7.5 \pm 6.6$ & (29 Jun) & 4 & $3.9 \pm 3.3$ & $1.8 \pm 1.8^{b}$ & $12.4 \pm 5.8$ & $4.6 \pm 1.9^{\mathrm{cd}}$ & $5.7 \pm 2.8$ \\
\hline $13.4 \pm 4.3$ & (30 Jun) & 5 & & $1.1 \pm 1.5^{\mathrm{d}}$ & & $1.9 \pm 1.2^{\mathrm{bcd}}$ & $4.8 \pm 2.4$ \\
\hline $18.8 \pm 6.9$ & (1 Jul) & 6 & $1.6 \pm 2.4$ & & & & \\
\hline $14 \pm 7.5$ & (2 Jul) & 7 & & & & & \\
\hline $21.5 \pm 7.6$ & (3 Jul) & 8 & $2.6 \pm 2.0$ & & & & \\
\hline $16.8 \pm 7.9$ & (4 Jul) & 9 & & & $13.8 \pm 5.2$ & & \\
\hline $12.5 \pm 6.0^{\mathrm{db}}$ & (5 Jul) & 10 & & $0.7 \pm 0.9^{d}$ & & & \\
\hline $1.7 \pm 1.3$ & (6 Jul) & 11 & & & $10.0 \pm 5.0^{b}$ & $6.5 \pm 2.8^{\mathrm{cd}}$ & $8.2 \pm 3.8$ \\
\hline & & 12 & & $0.8 \pm 1.1^{\mathrm{d}}$ & $9.8 \pm 5.5$ & $6.0 \pm 3.3^{\mathrm{cd}}$ & \\
\hline & & 13 & & & & $5.6 \pm 2.2^{\mathrm{cd}}$ & $11.7 \pm 4.6$ \\
\hline & & 14 & & $1.5 \pm 1.5^{d}$ & & & \\
\hline & & 15 & & $2.1 \pm 3.5^{b}$ & $10.6 \pm 4.8$ & $6.8 \pm 2.3^{\mathrm{cd}}$ & $10.7 \pm 4.1$ \\
\hline & & 16 & $5.3 \pm 3.5^{b}$ & & & $3.7 \pm 4.4 \mathrm{bcd}$ & $5.4 \pm 2.2$ \\
\hline & & 17 & $5.3 \pm 3.9$ & $3.0 \pm 2.9$ & $10.3 \pm 6.0$ & $8.2 \pm 3.6^{\mathrm{cd}}$ & $10.9 \pm 4.6$ \\
\hline & & 18 & & & $11.6 \pm 5.3$ & & \\
\hline & & 19 & & & $11.9 \pm 4.8^{\mathrm{bcd}}$ & & \\
\hline & & 20 & $6.0 \pm 3.2$ & $2.0 \pm 1.7^{b}$ & $6.5 \pm 4.7^{\circ}$ & $7.1 \pm 3.0^{\mathrm{cd}}$ & \\
\hline & & 21 & & & & $3.0 \pm 1.8^{\mathrm{cd}}$ & \\
\hline & & 22 & & $2.2 \pm 1.8$ & & & \\
\hline & & 23 & & & $11.0 \pm 5.3$ & & \\
\hline & & 24 & $4.7 \pm 2.9$ & $2.9 \pm 2.4^{\mathrm{d}}$ & $10.1 \pm 5.3$ & $7.6 \pm 3.44^{c t}$ & \\
\hline & & 25 & & & $11.4 \pm 5.9^{b}$ & & \\
\hline & & 26 & & & $9.8 \pm 4.1$ & & \\
\hline & & 27 & & & $6.4 \pm 4.2^{\mathrm{cd}}$ & & \\
\hline & & 28 & $15.3 \pm 8.6$ & & $11.0 \pm 4.8$ & $9.6 \pm 3.9^{c d}$ & \\
\hline & & 29 & & $0.4 \pm 0.6^{\mathrm{bd}}$ & $9.3 \pm 4.1$ & $11.0 \pm 3.4 \mathrm{~cd}$ & \\
\hline & & 30 & $7.5 \pm 5.3^{b}$ & $0.8 \pm 1.0^{\mathrm{bd}}$ & $9.3 \pm 5.7$ & $8.3 \pm 4.0^{\mathrm{cd}}$ & $8.1 \pm 5.5$ \\
\hline & & 31 & & & & $7.5 \pm 3.2^{\mathrm{cd}}$ & \\
\hline & & 32 & & & & $7.8 \pm 2.6^{\mathrm{cd}}$ & $14.4 \pm 6.0$ \\
\hline Avg. $12.0 \pm 5.8$ & & $5.8 \pm 4.0$ & $1.7 \pm 1.0$ & $10.5 \pm 2.0$ & $6.5 \pm 2.4$ & $8.5 \pm 3.3$ & \\
\hline${ }^{\mathrm{a}} \mathrm{Chl}$ a not measur & ed & & & ${ }^{c}$ Lipid $\mathrm{C}$ & not measured & & \\
\hline${ }^{b}$ Phytoplankton & mposition & t measur & & ${ }^{d}$ Length-s & ific weight of $f$ & es not measur & \\
\hline
\end{tabular}

$1994\left(r_{s}=-0.217\right)$. Several authors have reported positive relationships between egg production rates and chl a concentration only for the larger fraction $(>8,10$ or $11 \mu \mathrm{m}$ ) of chl $a$, as this size fraction often better represents the phytoplankton efficiently ingested than the total chl a (Bellantoni \& Petersen 1987, Peterson et al. 1991, Bautista et al. 1994, Dam et al. 1994, Kiørboe \& Nielsen 1994). In the present study, the $>8 \mu \mathrm{m}$ size fraction of chl a had the same effect on egg production as total chl a (April 1995, $\mathrm{r}_{\mathrm{s}}=0.064 ; A$. bifilosa in June/ July $1995, r_{s}=-0.69, p<0.05 ; A$. tonsa in June/July $1995, r_{\mathrm{s}}=-0.57$ ). This shows that the low egg production rates in the Pomeranian Bay in summer were caused by the large phytoplankton.

A further observation confirmed that the Pomeranian Bay is not very favourable for copepod egg production in summer. In August 1995, egg production rates of
Acartia tonsa were significantly lower in the Pomeranian Bay than in other areas of the Southern Baltic Sea (Mann-Whitney $U$-test, $\mathrm{p}<0.05$ ), although the chl a concentration was clearly higher there (Table 5).

The analyses of phytoplankton species composition during cruises in June/July 1994, June/July 1995 and August 1995 (Fig. 4) indicated that the presence of dinoflagellates had a positive effect on egg production of Acartia bifilosa and A. tonsa $\left(r_{s}=0.779, p<0.05\right)$ and that cyanobacterial filaments $\left(r_{s}=-0.515, p<0.05\right)$, and particularly cyanobacterial colonies $\left(r_{s}=-0.939\right.$, $p<0.05)$, had a negative effect. Diatoms $\left(r_{s}=0.26\right)$, chlorophytes $\left(r_{s}=0.23\right)$ and cryptophytes $\left(r_{s}=-0.293\right)$ showed no significant impact, even though their contribution to the total phytoplankton biomass was similar to that of the dinoflagellates. Single species blooms of the dinoflagellate Prorocentrum micans in the outer- 
a) June/July 1994

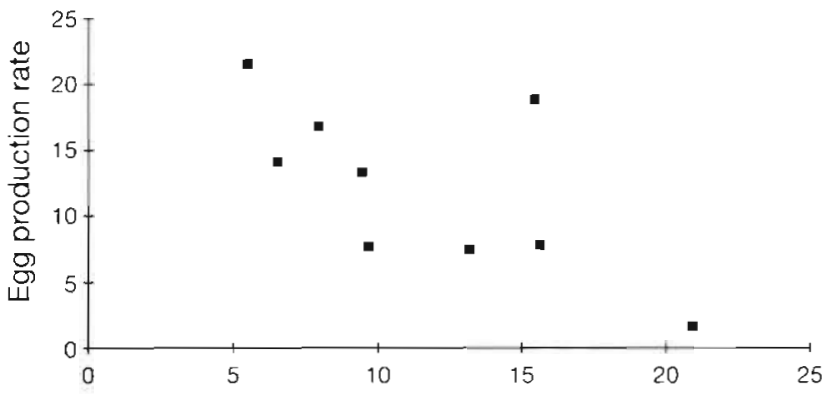

b) September 1994

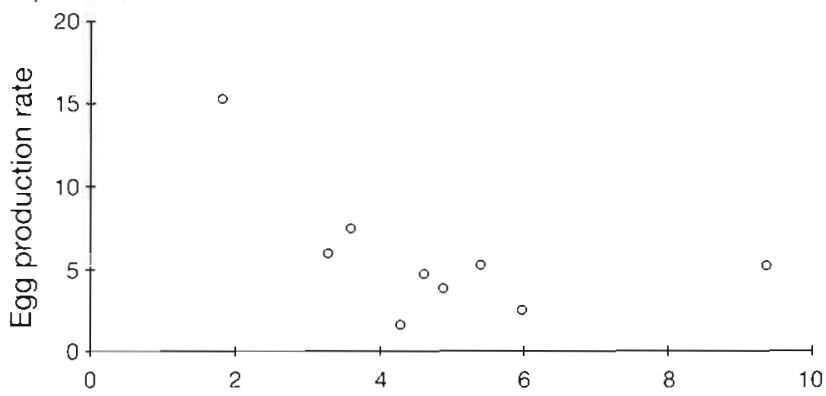

c) January 1995

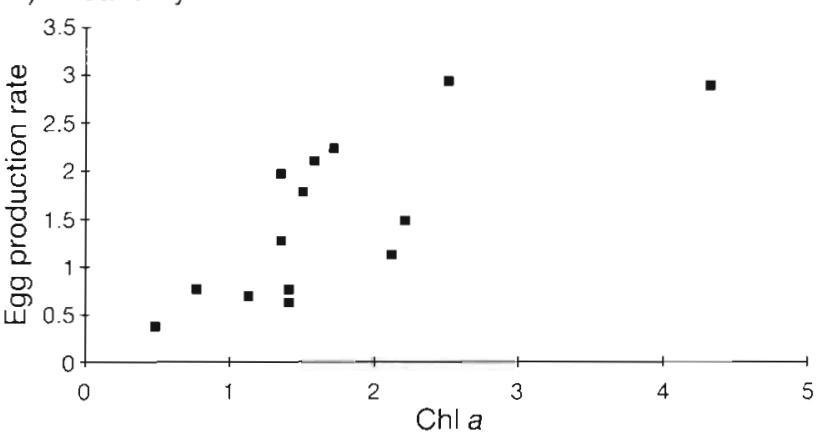

d) April 1995

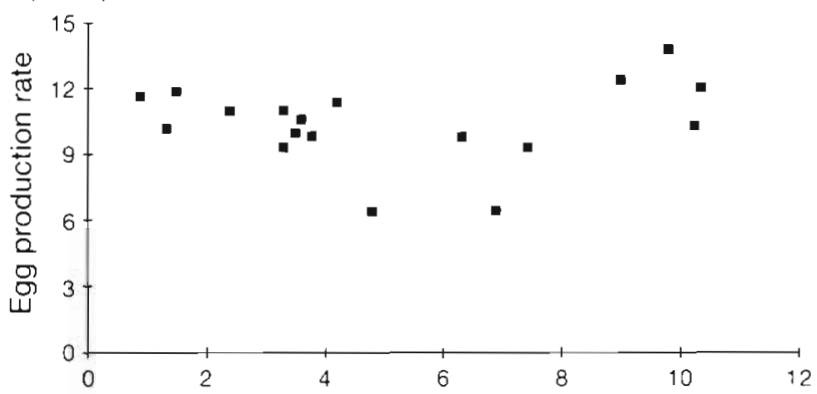

e) June/July 1995

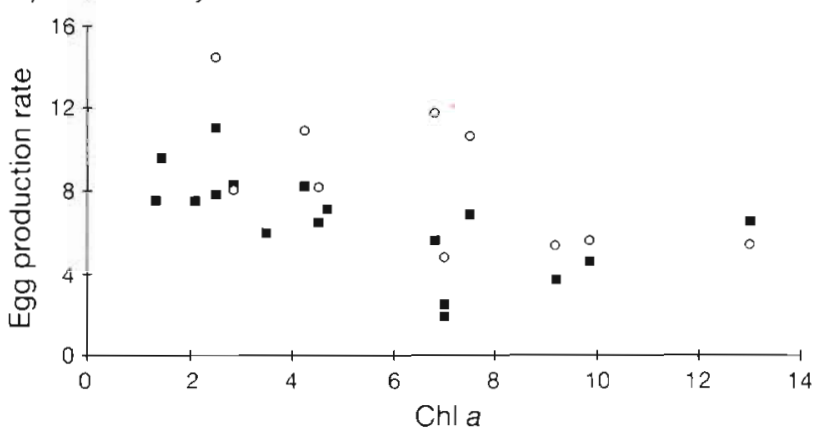

Fig. 3. Egg production rates (eggs female $e^{-1} \mathrm{~d}^{-1}$ ) as a function of the chl a concentration ( $\mu \mathrm{g} \mathrm{l}^{-1}$ ) during cruises in the

Pomeranian Bay. (-) Acartia bifilosa; (o) Acartia tonsa bay in September 1994 and of the diatom Skeletonema costatum in April 1995 were accompanied by high egg production rates even at lower total phytoplankton concentration.

\section{Physiological status}

Length-specific weight and lipid content confirm that females of Acartia bifilosa were in proper condition in April. Even though the ranges of the lengthspecific weights ( $\mathrm{\mu g} \mathrm{mm}^{-3}$ ) calculated for different seasons overlap (Fig. 5, Table 6), highest values were observed in April (Mann-Whitney $U$-test, $\mathrm{p}<0.01$ ). Values were similar in June/July 1994 and September 1994, but were significantly lower in January $1995(\mathrm{p}<0.01)$. There was
Table 5. Data from August 1995: physical properties, chl a concentration and egg production rate (EP) of Acartia bifjlosa and $A$. tonsa at stations in the Pomeranian Bay (PB) and neighbouring areas (Mecklenburg Bay [MB], Arkona Sea [AS], Bornholms Gatt [BG]). Average chl a concentration was integrated over the water column using the values of discrete depths: $0,2.5$, $5,10,20 \mathrm{~m}$ and bottom. Temperature at the chl a maximum and the maximum chl a concentration are shown in parentheses

\begin{tabular}{|c|c|c|c|c|c|c|c|}
\hline Area & Stn & $\begin{array}{c}\text { Depth } \\
(\mathrm{m})\end{array}$ & Temperat & $\begin{array}{l}\text { ure }(\max ) \\
\text { C) }\end{array}$ & $\begin{array}{l}\text { Chl a } \\
\text { (Ho }\end{array}$ & $\begin{array}{l}a(\max ) \\
\left.g \mathrm{j}^{-1}\right)\end{array}$ & $\begin{array}{c}\mathrm{EP} \pm \mathrm{SD} \\
(\text { eggs female } \\
\mathrm{d}^{-1} \text { ) }\end{array}$ \\
\hline PB & 4 & 10 & 21 & (21) & 10 & $(10.3)$ & $2.5 \pm 1.9$ \\
\hline PB & 7 & 13 & 21 & (21) & 7 & $(7.2)$ & $2.6 \pm 2.1$ \\
\hline $\mathrm{PB}$ & 13 & 13 & 22 & (21) & 7 & $(9.0)$ & $3.9 \pm 3.3$ \\
\hline PB & 19 & 16 & $22-14$ & (21) & 7 & $\{8.7\}$ & $2.9 \pm 2.0$ \\
\hline PB & 30 & 19 & $21-8$ & (21) & 3 & (5.5) & $3.6 \pm 2.3$ \\
\hline $\mathrm{PB}$ & 32 & 21 & $22-12$ & (22) & 5 & (8.5) & $3.6 \pm 2.2$ \\
\hline$B G$ & 06 & 65 & $21-6$ & (21) & 2 & $(3.6)$ & $23.6 \pm 8.2$ \\
\hline AS & 05 & 46 & $21-8$ & (21) & 2.5 & $(3.8)$ & $8.9 \pm 4.8$ \\
\hline AS & 04 & 46 & $21-7$ & (18) & 3 & $(5.6)$ & $13.9 \pm 7.6$ \\
\hline AS & 03 & 22 & $22-13$ & (20) & 2.5 & (3.3) & $7.2 \pm 4.1$ \\
\hline MB & 02 & 25 & $19-12$ & (17) & 1.5 & $(2.0)$ & $13.7 \pm 6.8$ \\
\hline MB & 01 & 23 & $19-12$ & (14) & 1.5 & $(1.9)$ & $20.4 \pm 8.2$ \\
\hline
\end{tabular}


a) Dinoflagellates

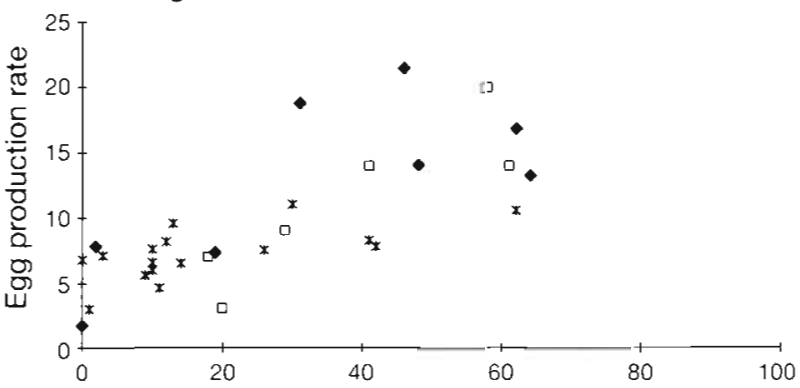

b) Cyanobacteria (colonies)

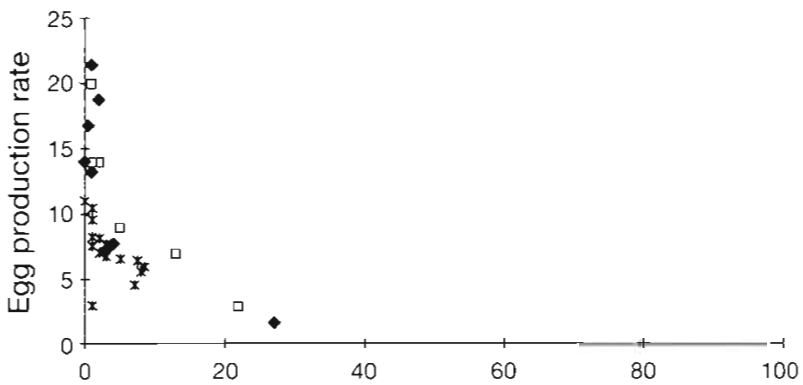

C) Cyanobacteria (filaments)

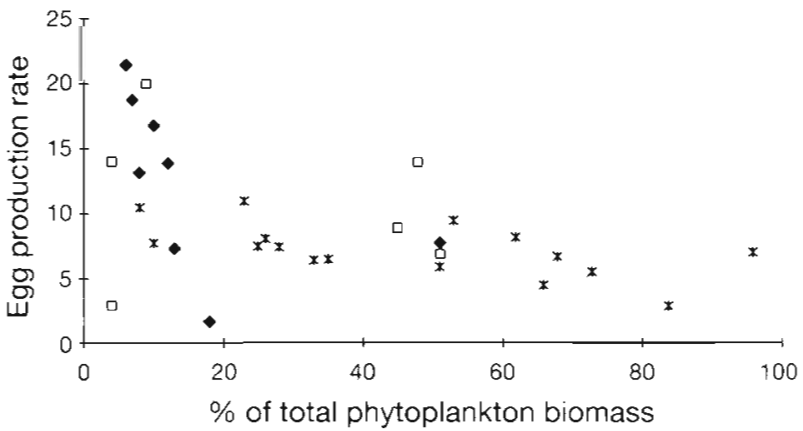

d) Diatoms

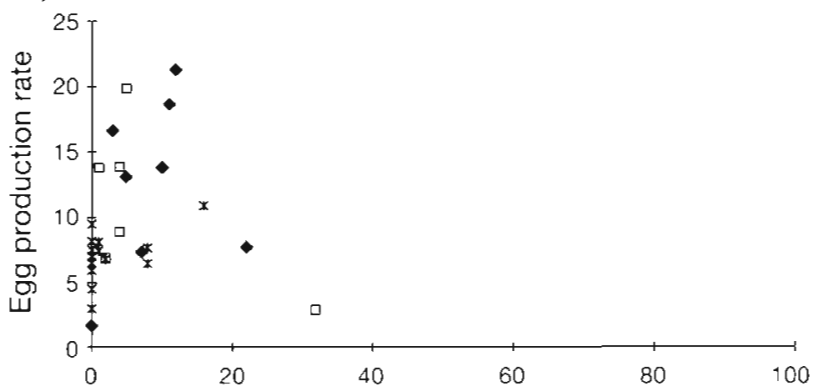

e) Chlorophytes

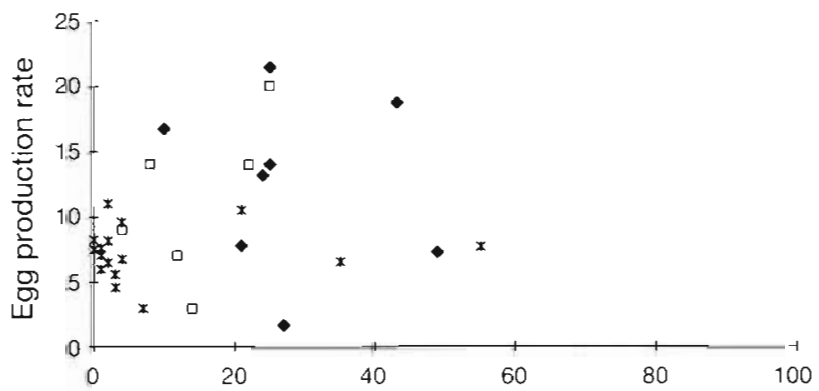

f) Cryptophytes

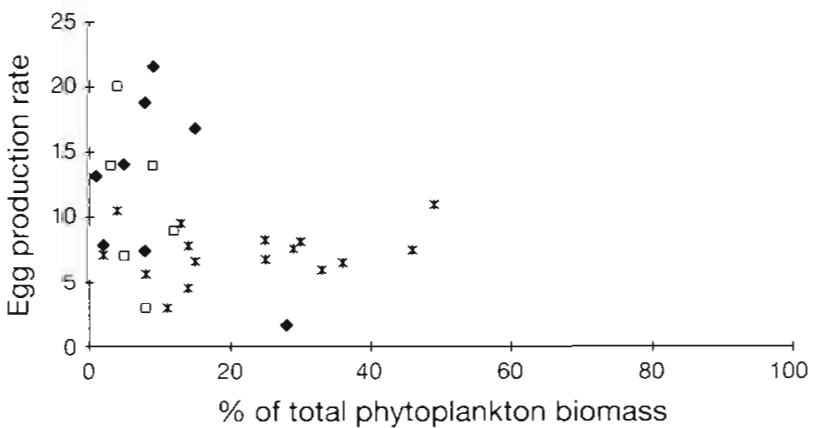

Fig, 4. Egg production rates (eggs female $e^{-1} \mathrm{~d}^{-1}$ ) as a function of the proportion of different phytoplankton groups contributing to total phytoplankton biomass ( $\$$ June/July 1994, (*) June/July 1995, (a) August 1995

also a positive relationship between the length-specific weight of females and measured egg production rate.

Lipids amounted to between 7 and $18 \%$ of the dry weight. Values were significantly higher in April than during other cruises (Mann-Whitney $U$-test, $\mathrm{p}<0.01$, Table 6). In general, the lipid content was estimated without replicates. Six duplicate measurements of the fat content differed by 0.2 to $0.6 \%$ of the dry weight only

\section{DISCUSSION}

In the present study, Acartia spp. egg production rates were measured at several stations of an estuary during 5 periods representing different seasons. Tem- perature was uniform within each period and cannot explain the observed differences in egg production rates. Since Acartia species are known to store only moderate amounts of lipid and to depend primarily on continuous feeding (Dagg 1977, Båmstedt et al. 1990, Norrbin 1990), recent food supply must be important. We related the measured egg production rates to the chl a concentration and to the relative abundance of taxonomic groups of the phytoplankton. The extent of carnivorous feeding by $A$. tonsa and $A$. bifilosa is assumed to be rather low in the Pomeranian Bay because, e.g., in autumn 1993 and summer 1994 the biomass of protozooplankton amounted only to a fraction ( 3 to $11 \%$ ) of that of the phytoplankton (Reckermann 1996) and because, in the mixed water column, large-cell phytoplankton is abundant even during summer. 


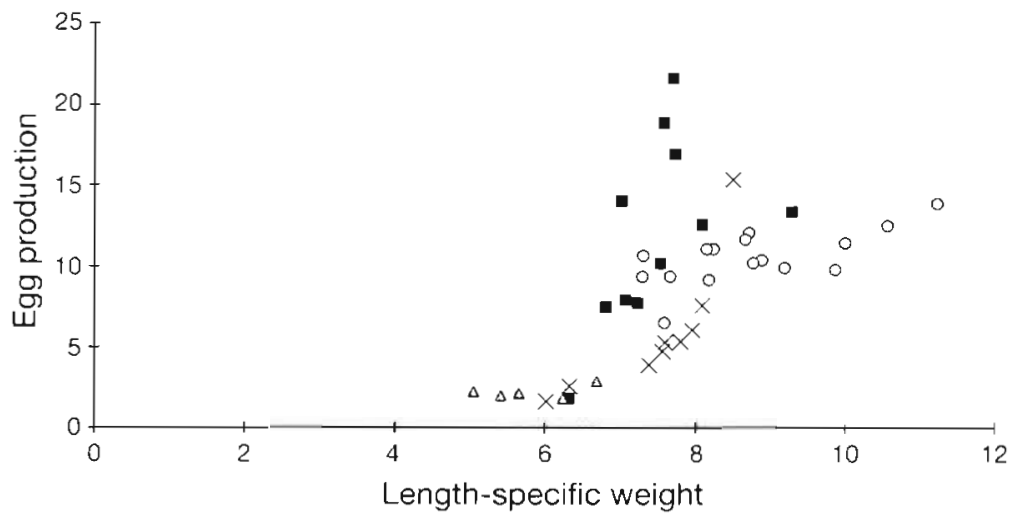

Fig. 5. Egg production rates (eggs female $e^{-1} \mathrm{~d}^{-1}, \pm \mathrm{SE}$ ) as a function of the length-specific weight of females $\left(\mu \mathrm{g} \mathrm{mm}^{-3}\right)$. ( ) June/July $1994\left(\mathrm{r}_{\mathrm{s}}=0.64, \mathrm{p}<\right.$ 0.05), Acartia bifilosa; $(\times)$ September $1994\left(\mathrm{r}_{\mathrm{s}}=1, \mathrm{p}<0.001\right)$, A. tonsa; (ه) January 1995 (no test), A bifilosa; (o) April $1995\left(r_{s}=0.59, p<0.05\right)$, A. bifilosa values, we suppose that it was primarily the quality of the food which had improved (as a result of the occurrence of the diatom Skeletonema costatum). This assumption is supported by measured $\mathrm{C}: \mathrm{N}$ ratios of the particulate organic matter: average ratios of $11 \pm 2.5$ in. January compared to $7.5 \pm 1.3$ in April (M. Voss unpubl. data). Laboratory studies have shown that the egg production of copepods may closely follow variations in the nitrogen content of ingested algae (Checkley 1980, Kiørboe 1989). A rapid increase in egg production of copepods during the spring bloom period has also been observed in other temperate environments (Peterson 1985, Tiselius et al. 1991, Kiørboe \& Nielsen 1994, Hay 1995, Pond et al. 1996) and implies that the production of perennial species is not prevented by low temperatures.

\section{Winter}

In the Pomeranian Bay, overwintering females of Acartia bifilosa maintained their egg production at a low level. The concomitant presence of a high percentage of males and nauplii (authors' unpubl. data) allow us to suppose that viable nauplii hatch from these eggs. A positive response of the egg production rate to an increase in the chl a concentration, as well as the low length-specific weight of females, implies that copepods were food limited during winter.

\section{Spring}

Nearly uniform egg production rates with varying chl a concentration suggest that food was not limiting in spring and that we observed maximum rates at the given conditions. The high length-specific weight of females and an increased lipid content also indicate good feeding conditions. As temperature was still low and chl a concentrations measured in April overlapped with January

Table 6. Acartia bifilosa and A. tonsa. Mean ( \pm SD) length-specific weight and lipid content of females during different cruises $(n=$ number of stations on which calculations are based)

\begin{tabular}{|llccr|}
\hline Cruise & Species & $\mathrm{n}$ & $\begin{array}{c}\text { Length-specific } \\
\text { weight }\left(\mu \mathrm{mm}^{-3}\right)\end{array}$ & $\begin{array}{c}\text { Lipid content } \\
(\% \text { dry weight })\end{array}$ \\
\hline June/July 1994 & A. bifilosa & 11 & $7.53 \pm 0.75$ & $9.73 \pm 1.64$ \\
September 1994 & A. tonsa & 9 & $7.47 \pm 0.81$ & $9.01 \pm 1.53$ \\
January 1995 & A. bifilosa & $5 / 14^{\mathrm{d}}$ & $5.82 \pm 0.66$ & $11.15 \pm 2.12$ \\
April 1995 & A. bifilosa & 16 & $8.79 \pm 1.13$ & $13.73 \pm 1.92$ \\
a $\mathrm{n}=5$ stations for length-specific weight and 14 stations for lipid content \\
\hline \multicolumn{5}{l}{} \\
\hline
\end{tabular}

\section{Summer/autumn}

In summer and autumn, egg production rates were often low in spite of high temperatures and large phytoplankton standing stocks, which included species which can be grazed efficiently. Length-specific weight and lipid content indicate that the nutrition of females was not optimal.

Analyses of the taxonomic composition of phytoplankton have shown that low egg production rates of Acartia spp. were accompanied by a high proportion of cyanobacteria in the total phytoplankton biomass. The adverse effect of cyanobacteria has also been observed in laboratory experiments, where the egg production of $A$. tonsa was reduced when the concentration of cyanobacteria (Microcystis aeruginosa, Nodularia spumigena) in a food mixture with a diatom became too high (Schmidt \& Jónasdóttir 1997). Several mechanisms by which cyanobacteria may affect the zooplankton negatively have been discussed (reviewed by Lampert 1987). Indigestibility and lack of essential nutrients can be excluded as a reason because cyanobacterial filaments and colonies were only ingested in low amounts by $A$. bifilosa in the Pomeranian Bay (Meyer-Harms \& von Bodungen 1997). Even if copepods are in principle able to avoid the ingestion of large cyanobacteria, high concentrations, or a high proportion in the total phytoplankton, may interfere with the uptake of other, more valuable, food. Probably filaments and colonies with gelatinous 
sheaths stick to the feeding appendages and their rejection is time consuming. Direct observations of the feeding behaviour of Acartia spp. in ambient water might clarify the mechanism. Although ingestion rates of cyanobacteria were low, an effect of cyanobacterial toxins cannot be excluded, since this depends on their dose and accumulation in the copepods.

Highest egg production rates coincided with high proportions of different dinoflagellate species in the total phytoplankton biomass in summer and with the bloom of the dinoflagellate Prorocentrum micans at outer stations of the bay in autumn. The biochemical composition of dinoflagellates suggests a high nutritional quality (Hitchcock 1982), and this has been supported by both laboratory (Jónasdóttir 1994) and field studies (Kleppel et al. 1991). In the latter study, correlations between egg production rates of Acartia tonsa and dietary microplankton biomass became stronger as the food supply changed from diatoms $\left(r^{2}=0.13\right)$ to dinoflagellates $\left(r^{2}=0.39\right)$ to ciliates $\left(r^{2}=0.51\right)$. It was highest in a mixed diet of dinoflagellates and ciliates $\left(r^{2}=0.71\right)$

The positive effect of a high proportion of dinoflagellates in the phytoplankton of the Pomeranian Bay may not be related to their nutritional quality only but also to a change in the copepods' feeding behaviour. Acartia tonsa is known to switch between 2 different feeding modes in accordance with the relative concentrations of alternative prey (Kiørboe et al. 1996): either generating a feeding current to encounter nonescaping prey (suspension feeding) or capturing motile items detected by means of mechanoreceptors (ambush feeding). The suspension feeding mode is more prone to obstruction due to mechanical interference by cyanobacteria. Since a high proportion of motile, relatively large, dinoflagellates can motivate copepods to preferentially employ the ambush feeding mode, the interference of cyanobacteria would be reduced. Additionally, other motile prey of lower relative concentration (protozooplankton) can be included in the diet.

Ambush feeding is only economical with large food particles in sufficient concentration. In phytoplankton samples collected in summer, dinoflagellates were nearly 10 -fold larger by volume than cryptophytes. This may explain why similarly high proportions of cryptophytes were not accompanied by increased egg production rates, even though they are also known to be a valuable diet for copepods (Støttrup et al. 1986, Støttrup \& Jensen 1990).

The use of taxonomic composition as a descriptor of food quality in the field studies is being disputed (Kleppel \& Burkart 1995) because nutritional distinctions between groups may vary with cell size (Kleppel 1993) and growth condition of the algae (Kiørboe 1989, Jónasdóttir 1994). As an alternative, the biochemical composition of the bulk or size-fractionated seston has been studied in a spring bloom situation (Jónasdóttir et al. 1995) as well as in an annual cycle (Pond et al. 1996). However, 2 aspects of food quality may have an effect in the field, one is the ingestibility of potential food, the other is the nutritional value of the particles actually ingested. Thus, the nutritional value of the seston may be irrelevant if morphological unsuitability or toxicity of certain phytoplankton species adversely affects food uptake, or if copepods select for certain items of seston not only by size but also by nutritional quality (Huntley et al. 1983, Vanderploeg 1990, Kleppel 1993). In studies of copepod egg production these 2 aspects of food quality can be separated when measurements on amount and composition of ingested food are included.

Our study showed that in the Pomeranian Bay egg production of Acartia spp. is primarily determined by the abundance and quality of phytoplankton, where the quality is not only a function of the nutritional value, but also of the manageability of potential food items (including behavioural responses of the copepods). The effect of temperature appears to be secondary, since (1) significant differences in egg production rates were observed at uniform temperature, (2) during the spring bloom the egg production rates and the length-specific weight of Acartia bifilosa increased much more strongly than expected from the slight rise in temperature and (3) the period of high temperature often coincided with poor food quality and, therefore, potentially higher egg production rates could not be expressed.

On the other hand, different temperature preferences of Acartia bifilosa and A. tonsa may be important in shaping the succession pattern of these 2 species in the Pomeranian Bay. A. bifilosa females survive winter actively and can make use of the spring bloom, while $A$. tonsa resting eggs do not hatch until $10^{\circ} \mathrm{C}$ is reached (Zillioux \& Gonzalez 1972, Arndt 1985). In turn, A. tonsa becomes superior to A. bifilosa during summer and can profit from the fall bloom.

Acknowledgements. The present study was funded by the German Bundesminister für Bildung, Wissenschaft, Forschung und Technologie (BMFT) as part of the joint research programme on exchange and transformation processes in the Pomeranian Bay ('TRUMP': 03F0105B). We are grateful to the crews of the RVS 'Alexander v. Humboldt' and 'Prof. Albrecht Penck' for assistance during the field sampling, to $\mathrm{D}$. Menzel for phytoplankton identifications and to Dr M. L. Hubert for support on statistical analyses. For helpful discussions, we thank Drs T. Kiørboe, M. Reckermann, S. H. Jónasdóttir, and C. Eichner.

\section{LITERATURE CITED}

Ambler JW (1985) Seasonal factors affecting egg production and viability of eggs of Acartia tonsa Dana from East Lagoon, Galveston, Texas. Estuar Coast Shelf Sci 20: 743-760 
Ambler JW (1986) Effects of food quantity and quality on egg production of Acartia tonsa Dana from East Lagoon, Galveston, Texas. Estuar Coast Shelf Sci 23:183-196

Arndt H (1985) Untersuchungen zur Planktonökologie der Zooplankter eines inneren Küstengewässers der Ostsee. $\mathrm{PhD}$ thesis, Universität Rostock

Båmstedt U (1988) Ecological significance of individual variability in copepod bioenergetics. Hydrobiologia 167/168 $43-59$

Båmstedt U, Hảkanson JL, Brenner-Larsen J, Björnsen PK, Geertz-Hansen O, Tiselius P (1990) Copepod nutritional condition and pelagic production during autumn in Kosterfjorden, western Sweden. Mar Biol 104:197-208

Bautista B, Harris RP, Rodriguez V, Guerrero F (1994) Temporal variability in copepod fecundity during two different spring bloom periods in coastal waters off Plymouth (SW England). J Plankton Res 16:1367-1377

Beckman BC. Peterson WT (1986) Egg production of Acartia tonsa Dana in Long Island Sound. J Plankton Res 8: $917-925$

Bellantoni DC, Peterson WT (1987) Temporal variability in egg production rates of Acartia tonsa Dana in Long Island Sound. J Exp Mar Biol Ecol 107: 199-208

Behrendt H. Krocker M (1990) A method for separation of zooplankton in high eutrophic water bodies. Limnologica 20:79-81

Cahoon LB (1981) Reproductive response of Acartia tonsa to variations in food ration and quality. Deep-Sea Res 28A: $1215-1221$

Castel J, Feurtet A (1989) Dynamics of the copepod Eurytemora affinis hirundoides in the Gironde estuary: origin and fate of its production. Sci Mar 53:577-584

Checkley DM (1980) Food limitation of egg production by a marine planktonic copepod in the sea off southern California. Limnol Oceanogr 25:991-998

Cowles TJ (1979) The feeding response of copepods from the Peru upwelling system: food size selection. J Mar Res 37 $601-622$

Dagg M (1977) Some effects of patchy food environments on copepods. Limnol Oceanogr 22:99-107

Dagg M (1978) Estimated, in situ, rates of egg production for the copepod Centropages typicus (Kroyer) in the New York Bay. J Exp Mar Biol Ecol 34:183-196

Dam HG, Peterson WT, Bellantoni DC (1994) Seasonal feeding and fecundity of the calanoid copepod Acartia tonsa in Long Island Sound: is omnivory important to egg production? Hydrobiologia 292/293:191-199

Donaghay PL (1985) An experimental test of the relative significance of food quality and past feeding history to limitation of egg production of the estuarine copepod Acartia tonsa. Arch Hydrobıol Beih Ergebn Limnol 21:235-245

Durbin EG, Durbin AG, Smayda TJ, Verity PG (1983) Food limitation of production by adult Acartia tonsa in Narragansett Bay, Rhode Island. Limnol Oceanogr 28:1199-1213

Durbin EG, Durbin AG, Campbell RG (1992) Body size and egg production in the marine copepod Acartia hudsonica during a winter-spring diatom bloom in Narragansett Bay. Limnol Oceanogr 37:342-360

Edler L (1979) Recommendations on methods for marine biological studies in the Baltic Sea. Phytoplankton and Chlorophyll. Baltic Mar Biol Publ 5

Frost BW (1972) Effects of size and concentration of food particles on the feeding behaviour of the marine planktonic copepod Calanus pacificus. Limnol Oceanogr 17:805-81.5

Gifford DJ, Dagg MJ (1991) The microzooplankton-mesozooplankton link consumption of planktonic protozoa by the calanoid copepods Acartia tonsa Dana and Neocalanus plumchrus Murukawa. Mar Microb Food Webs 5:161-177

Harrison KE (1990) The role of nutrition in maturation, reproduction and embryonic development of decapod crustaceans: a review. J Shellfish Res 9:1-28

Hay SJ (1995) Egg production and secondary production of common North Sea copepods: field estimates with regional and seasonal comparisons. ICES J Mar Sci 52: $315-327$

Hitchcock GL (1982) A comparative study of the sizedependent organic composition of marine diatoms and dinoflagellates. J Plankton Res 4:363-377

Huntley ME, Barthel KG, Star JL (1983) Particle rejection by Calanus pacificus: Discrimination between similar sized particles. Mar Biol 74:151-160

Ianora A, Buttino I (1990) Seasonal cycle in population abundance and egg production rates in the planktonic copepods Centropages typicus and Acartia clausii. J Plankton Res 12:473-481

Ianora A, Poulet SA, Miralto A (1994) A comparative study of the inhibitory effect of diatoms on the reproductive biology of the copepod Temora stylifera. Mar Biol 212: $533-539$

Ianora A, Scotto di Carlo B (1988) Observations on egg production rates and seasonal changes inthe internal morphology of Mediterranean populations of Acartia clausi and Centropages typicus. Hydrobiologia 167/168:247-253

Jónasdóttir SH (1994) Effects of food quality on the reproductive success of Acartia tonsa and Acartia hudsonica: laboratory observations. Mar Biol 121:67-81

Jónasdóttir SH, Fields D, Pantoja S (1995) Copepod egg production in Long Island Sound, USA, as a function of the chemical composition of seston. Mar Ecol Prog Ser 119 : $87-98$

Kimmerer WJ, McKinnon AD (1987) Growth, mortality, and secondary production of the copepod Acartia tranteri in Westernport Bay, Australia. Limnol Oceanogr 32:14-28

Kiørboe $T$ (1989) Phytoplankton growth rate and nitrogen content: implication for feeding and fecundity in a herbivorous copepod. Mar Ecol Prog Ser 55:229-234

Kiørboe T, Johansen K (1986) Studies of a larval herring (Clupea harengus L.) patch in the Buchan area. IV. Zooplankton distribution and productivity in relation to hydrographic features. Dana 6:37-51

Kiorboe T, Nielsen TG (1994) Regulation of zooplankton biomass and production in a temperate, coastal ecosystem. 1. Copepods. Limnol Oceanogr 39:493-507

Kiorboe T, Møhlenberg F, Hamburger K (1985) Bioenergetics of the planktonic copepod Acartia tonsa: relation between feeding, egg production and respiration, and composition of specific dynamic action. Mar Ecol Prog Ser 26:85-97

Kiørboe T, Møhlenberg F, Tiselius P (1988) Propagation of planktonic copepods: production and mortality of eggs. Hydrobiologia 167/168:219-225

Kiørboe T, Saiz E, Viitasalo M (1996) Prey switching behaviour in the planktonic copepod Acartia tonsa. Mar Ecol Prog Ser 143:65-75

Kleppel GS (1992) Environmental requlation of feeding and egg production by Acartia tonsa off southern California. Mar Biol 112:57-65

Kleppel GS (1993) On the diets of calanoid copepods. Mar Ecol Prog Ser 99:183-195

Kleppel GS, Burkart (1995) Egg production and the nutritional environment of Acartia tonsa: the role of food qua]ity in copepod nutrition. ICES J Mar Sci 52:297-304

Kleppel GS, Holliday DV, Pieper RE (1991) Trophic interactions between copepods and microplankton: a question about the role of diatoms. Limnol Oceanogr 36:172-178 
Laabir M, Poulet SA, Ianora A (1995) Measuring production and viability of eggs in Calanus helgolandicus. J Plankton Res 17:1125-1142

Lampert W (1987) Laboratory studies on zooplankton-cyanobacteria interactions. NZ J Mar Freshwat Res 21:483-490

Landry MR (1978) Population dynamics and production of a planktonic marine copepod, Acartia clausii, in a small temperature lagoon on San Juan Island, Washington. Int Rev Ges Hyrobiol 63:77-119

Marshall SM. Orr AP (1952) On the biology of Calanus finmarchicus. VII. Factors affecting egg production. J Mar Biol Assoc UK 30:527-547

Meyer-Harms B, von Bodungen B (1997) Taxon specific ingestion rates of natural phytoplankton by calanoid copepods in an estuarine environment (Pomeranian Bight. Baltic Sea) determined by cell counts and HPLC analyses of marker pigments. Mar Ecol Prog Ser 153:181-190

Mueller-Navarra D, Lampert W (1996) Seasonal patters of food limitation in Daphnia galeata: separating food quantity and food quality effects. J Plankton Res 7:1137-1157

Norrbin MF, Olsen RE, Tande KS (1990) Seasonal variation in lipid class and fatty acid composition of two small copepods in Balsfjorden, northern Norway. Mar Biol 105: $205-211$

Petersen WT (1985) Abundance, age structure and in situ egg production rates of the copepod Temora longicornis in the Long Island Sound, New York. Bull Mar Sci 37(2): $726-738$

Petersen WT, Tiselius P, Kiørboe T (1991) Copepod egg production, moulting and growth rates, and secondary production, in the Skagerrak in August 1988. J Plankton Res 13:131-154

Pond D, Harris R, Head R, Harbour D (1996) Environmental and nutritional factors determining seasonal variability in the fecundity and egg viability of Calanus helgolandicus in coastal waters off Plymouth, UK. Mar Ecol Prog Ser 143: $45-63$

Reckermann (1996) Ultraphytoplankton and protozoan communities and their interactions in different marine pelagic ecosystems (Arabian Sea and Baltic Sea). Mar Sci Rep Baltic Sea Res Inst 14

Saiz E, Calbet A, Trepat I, Irigoien X, Alcaraz M (1997) Food availability as a potential source of bias in the egg production method for copepods. J Plankton Res 19:1-14

Editorial responsibility: Otto Kinne (Editor),

Oldendorf/Luhe, Germany
Sargent JR, Falk-Petersen S (1988) The lipid biochemistry of calanoid copepods. Hydrobiologia 167/168:101-114

Schmidt K, Jónasdóttir SH (1997) Nutritional quality of two cyanobacteria. How rich is 'poor' food? Mar Ecol Prog Ser 151:1-10

Støttrup JG, Jensen J (1990) Influence of algal diet on feeding and egg-production of the calanoid copepod Acartia tonsa Dana. J Exp Mar Biol Ecol 141:87-105

Stottrup JG, Richardson K, Kirkegaard E, Pihl NJ (1986) The cultivation of Acartia tonsa Dana for use as a live food source for marine fish larvae. Aquaculture 52:87-96

Tiselius $P$, Nielsen TG, Breuel G, Jaanus A, Korshenko A, Witek Z (1991) Copepod egg production in the Skagerrak during SKAGEX, May-June 1990. Mar Biol 111:445-453

Uye S, Shibuno N (1992) Reproductive biology of the planktonic copepod Paracalanus sp. in the Inland Sea of Japan J Plankton Res 14:343-359

Vanderploeg HA (1990) Feeding mechanisms and particle selection in suspension-feeding zooplankton. In: Wotton RS (ed) The biology of particles in aquatic systems. CRC Press, Boca Raton, p 191-197

Vanderploeg HA, Paffenhöfer GA, Liebig JR (1988) Diaptomus v5 net phytoplankton: effects of algae size and morphology on selectivity of a behaviorally flexible, omnivorous copepod. Bull Mar Sci 43:377-394

Viitasalo M, Katajisto T, Vuorinen I (1994) Seasonal dynamics of Acartia bifilosa and Eurytemora affinis (Copepoda: Calanoida) in relation to abiotic factors in the norther Baltic Sea. Hydrobiologia 292/293:415-422

White JR, Roman MR (1992) Egg production by the calanoid copepod Acartia tonsa in the mesohaline Chesapeake Bay: the importance of food resources and temperature. Mar Ecol Prog Ser 86:239-249

Zillioux EJ, Gonzalez JG (1972) Egg dormancy in a neritic calanoid copepod and its implications to overwintering in boreal water. In: Battaglia B (ed) Factors affecting biological equilibria in the Adriatic brackish water lagoons. 5th European Marine Biology Symposium. Piccin Editore, Padua, p 217-230

Zöllner N, Kirsch K (1962) Über die quantitative Bestimmung von Lipoiden (Micromethode) mittels der vielen natürlichen Lipoiden (alle bekannten Plasmalipoiden) gemeinsamen Sulfophosphovanillin-Reaktion. Z Ges Exp Med 135:545-561

Submitted: May 2, 1997; Accepted: August 4, 1998 Proofs received from a uthor(s): November 3, 1998 